\title{
Conservation of large avian frugivores and the management of Neotropical protected areas
}

\author{
Stuart D. Strahl and Alejandro Grajal
}

Large frugivorous forest birds are among the most endangered avian groups in the Neotropics. Despite this fact, there has been little field work on members of these groups or on other large Neotropical forest birds. While current studies of Neotropical forests are beginning to provide data for reserve management at the ecosystem level, we lack information for management of particular species or habitats. Throughout Latin America, large forest frugivores are economically important as food, as pets or in local crafts. They can also be important seed dispersers and can be used as indicator species of habitat disturbance in protected areas. The conservation status of these birds demands more attention and commitment from conservation organizations and the scientific community in general. Further field research should focus on the basic ecology and natural history of endangered and non-endangered species. These studies will aid in developing badly needed long-term management and monitoring plans both for populations of large forest frugivores and their habitats.

\section{Introduction}

Nearly one-eighth of the 3800 species of Neotropical avifauna are endangered or vulnerable (Collar and Andrew, 1988; World Resources Institute, 1990). Many of these are large forest frugivores, especially of the families Cracidae (guans and curassows), Psittacidae (parrots), Tinamidae (tinamous), Ramphastidae (toucans) and Psophiidae (trumpeters). Nearly 40 per cent of the 48 species of larger Neotropical parrots and macaws are listed as endangered, threatened or vulnerable (Collar and Andrew, 1988). Of the 36 species of guans and curassows, 18 species ( 50 per cent) are endangered or vulnerable, and an additional six subspecies are threatened (Strahl, in press). The status of most toucans, tinamous and trumpeters is virtually unknown.

Given their vulnerability and their ecological and economic importance, the lack of more field research on the basic biology of these birds should be of major concern. Conservation biologists, park managers and ornithologists must dedicate more research efforts to these Neotropical birds. These studies should be linked to the management and conservation of protected areas. The purpose of this paper is to outline the biological and economic importance of these species, point out specific information gaps and present recommendations for future research.

\section{Biological and socio-economic importance of large Neotropical forest frugivores}

Avian frugivores can be important seed dispersers or seed predators in forest ecosystems (e.g. Janzen, 1983; Wheelwright, 1983; Diamond and Lovejoy, 1985; Estrada and Fleming, 1986). Large avian frugivores ( $>700$ g) can contribute $60-75$ per cent of the total biomass of avian seed dispersers in Neotropical forest ecosystems (Terborgh, 1986; Erard and Sabatier, 1988).

These species also have direct and indirect economic value. Virtually all studies on subsis- 


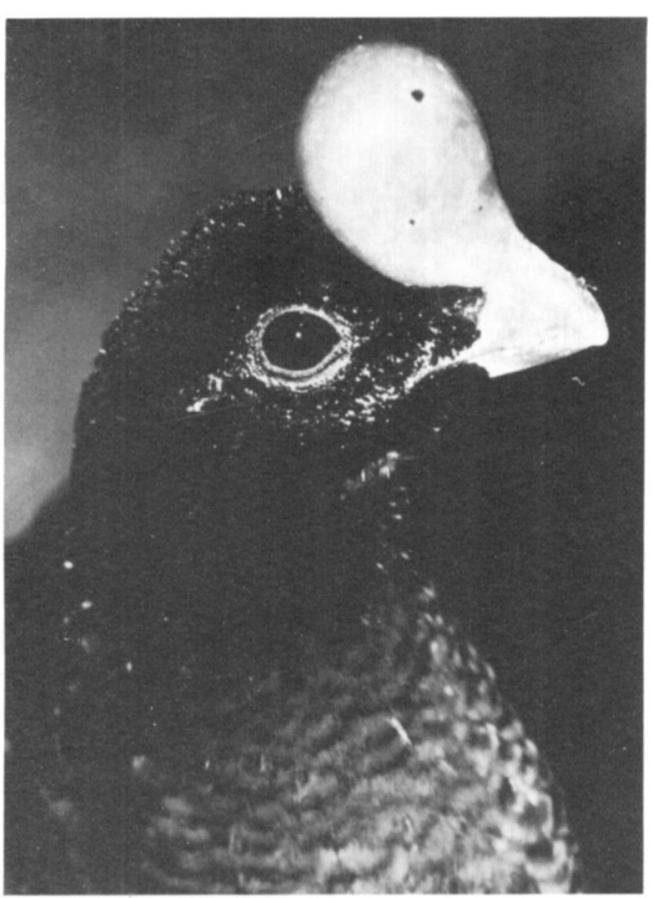

The rare brown phase of the female northern helmeted curassow Pauxi pauxi. This endangered species is rapidly disappearing from its former range in Venzuela and Colombia due to widespread hunting and habitat destruction (S. D. Strahl/WCINew York Zoological Society).

tence hunting in the Neotropics show that large avian frugivores are among the most important sources of protein for rural peasants and native

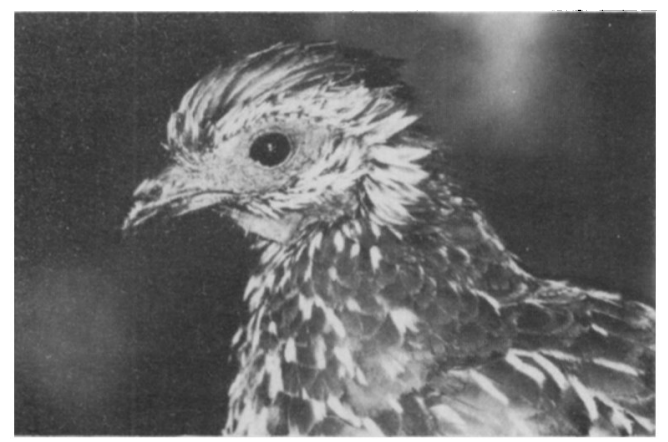

The band-tailed guan Penelope argyrotis. Excellent indicator of Andean slope cloud forests in Venezuela/Colombia. Locally threatened, but common in undisturbed forests. A good species for inclusion in monitoring programmes

(S. D. Strahl/WCI-New York Zoological Society).

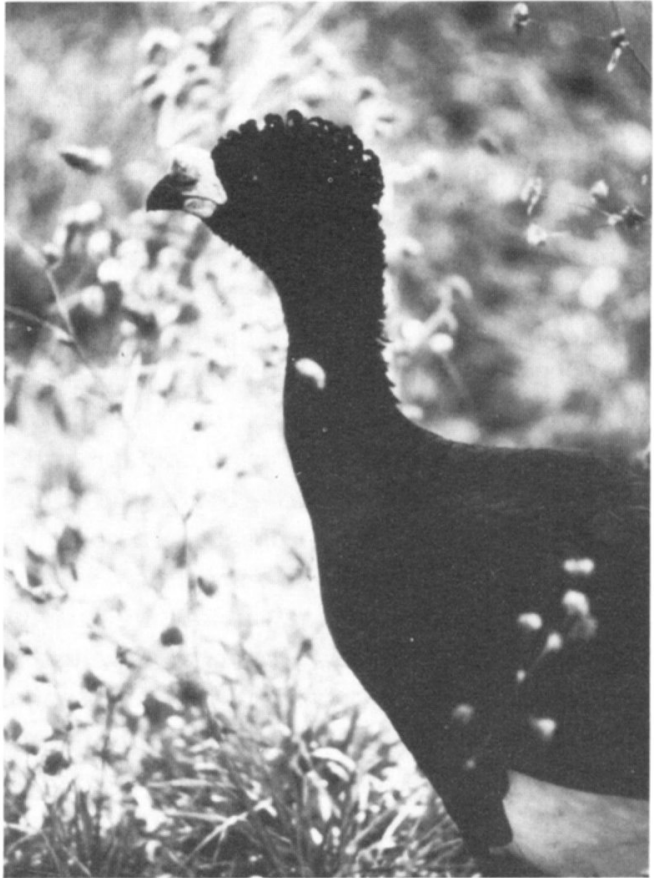

In-depth studies of non-endangered species such as the yellow-knobbed curassow Crax daubentoni can shed light on the biology of more threatened forms, while simultaneously producing critical data for management programmes (S. D. Strahl/WCI-New York Zoological Society).

Indian populations (Robinson and Redford, in press). Generally, guans and curassows rank as the highest category of avian biomass taken by subsistence hunters, followed closely by tinamous, trumpeters, parrots and toucans. Additionally, some species are hunted by peasants and native indians for use in local crafts or ceremonial purposes. Some large forest frugivores are also major game birds for sport hunters, especially the cracids and tinamous. Although this has fewer direct benefits for local human populations, licensing fees and money spent at hunting sites can be an economic incentive for the management of wild populations of certain species.

Finally, the trade in live birds for the pet market, expecially of parrots and toucans, is an important economic activity in many Neotropical regions. In particular, parrots and macaws have been vigorously persecuted (Roet et al. in Pasquier, 1981; Nilsson, 1985; 
Broad, 1986). Recent reports from the Orinoco River Delta in Venezuela indicate that up to 10,000 macaws (Ara spp.) were illegally exported per month during 1986-87, leading to disastrous declines in local populations (Desenne and Strahl, in press). In some extreme cases, the pet trade has contributed to the virtual extinction in the wild of rare species, such as the Spix's macaw (Ridgely, 1981; Thomsen and Munn, 1988).

\section{Large avian frugivores as management tools}

Because of their ecological and economic importance, the conservation and monitoring of large avian frugivores should be an essential part of the management of Neotropical protected areas. For only a handful of forest reserves and national parks in Latin America are there specific procedures for monitoring their health. The need for the development and implementation of such plans and procedures is obvious. In particular, avian families such as Cracidae and Tinamidae can be of significant importance as indicators of hunting pressure and/or habitat destruction. For instance, the Cracidae are easily censused, long-lived, are major target species and their populations respond very quickly to hunting or habitat disturbance (Silva and Strahl, in press). Similarly, parrots and toucans can be used to estimate population declines due to live trapping, hunting pressure or habitat disturbance. In short, monitoring changes in abundance in large frugivores can be an important component of management programmes, as the status of these species often reflects the conservation status of the protected area as a whole.

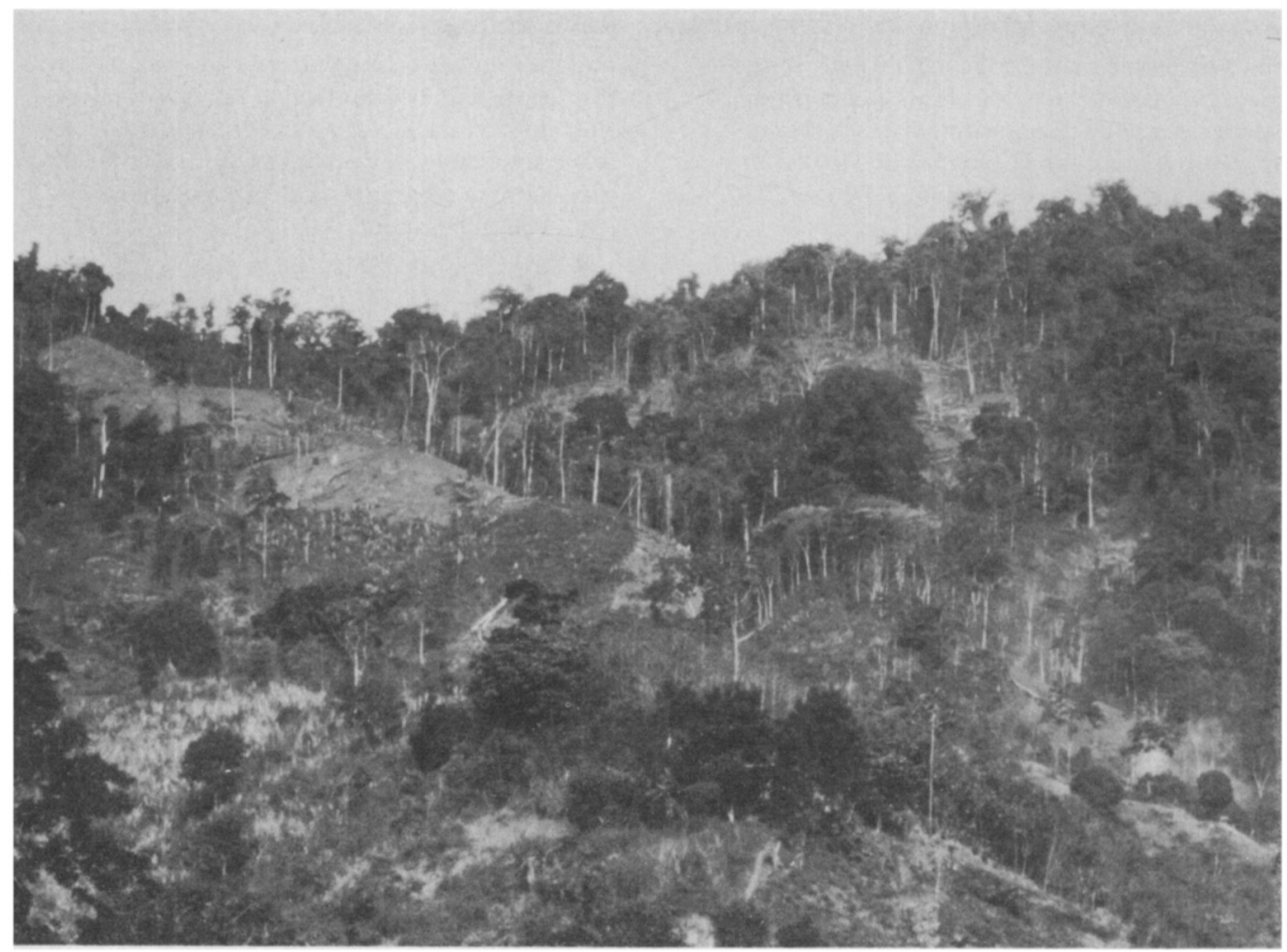

Habitat destruction in north-central Venezuelan mountain range. Although such obvious forms of human intervention can be directly measured, other disturbances can best be estimated through monitoring programmes of wildlife (especially those species susceptible to hunting) (S. D. Strahl/WCI-New York Zoological Society). 


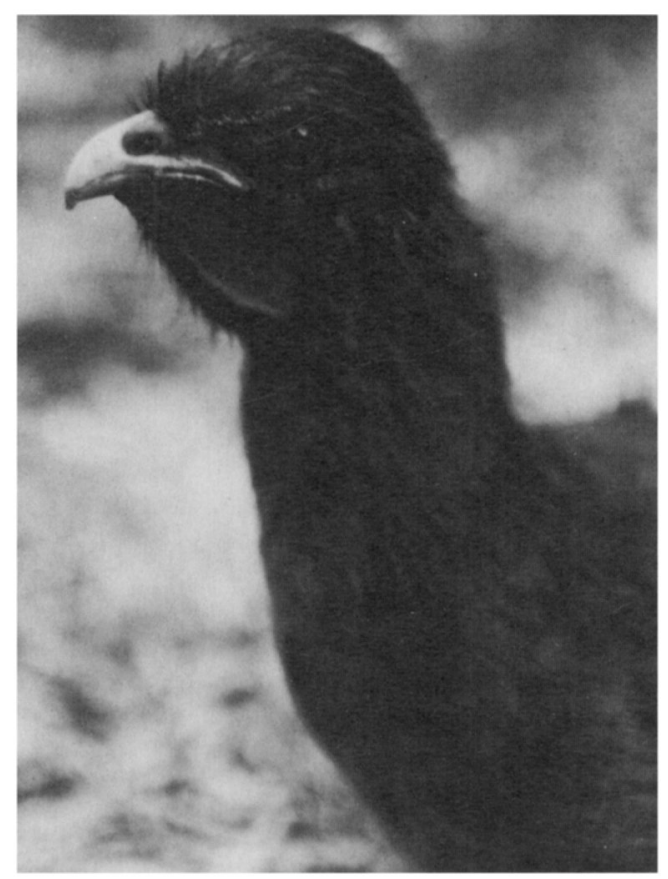

Rufous-vented Chachalaca Ortalis ruficauda. Somewhat adaptable to disturbed areas, a good indicator of ecotone areas. Common in Venezuela (S. D. Strahl/WCI-New York Zoological Society).

\section{Trend in research and future directions}

Very little literature exists on the ecology and natural history of large Neotropical forest birds. While there is growing interest in these families among Neotropical biologists, relatively little detailed field work has been undertaken over the last decade, with the exception of a few isolated studies on endangered species (e.g. Texeira and Snow, 1981; Lanning and Shiflett, 1983). Only 19 publications on the field biology of the families Psittacidae, Cracidae, Ramphastidae and Tinamidae appeared in international ornithological journals during this period, of which 15 were short notes.

The lack of basic life-history data on these groups is alarming, especially considering their importance as seed dispersers and their economic importance for local human populations. Therefore, basic studies on population dynamics, censusing methods and basic natural history must become a priority. These studies should include not only short-term census- es, but detailed long-term studies that should provide the necessary baseline information for application to management models.

Furthermore, it is imperative that the international community define research priorities for large forest birds beyond the endangered species research or 'lifeboat' strategies. Studies on the status and ecology of highly endangered species should be accompanied by detailed research programmes on non-endangered species within these families (Leck, 1979; Erard and Sabatier, 1988; Thiollay, 1989). We cannot merely continue 'lifeboat' operations on endangered species to the exclusion of studies of their commoner relatives. The latter can serve as reference points for investigations of endangered congeners and will provide baseline data for future conservation arguments. Therefore, studies on endangered species of large forest frugivores and their less-threatened relatives should be complementary parts

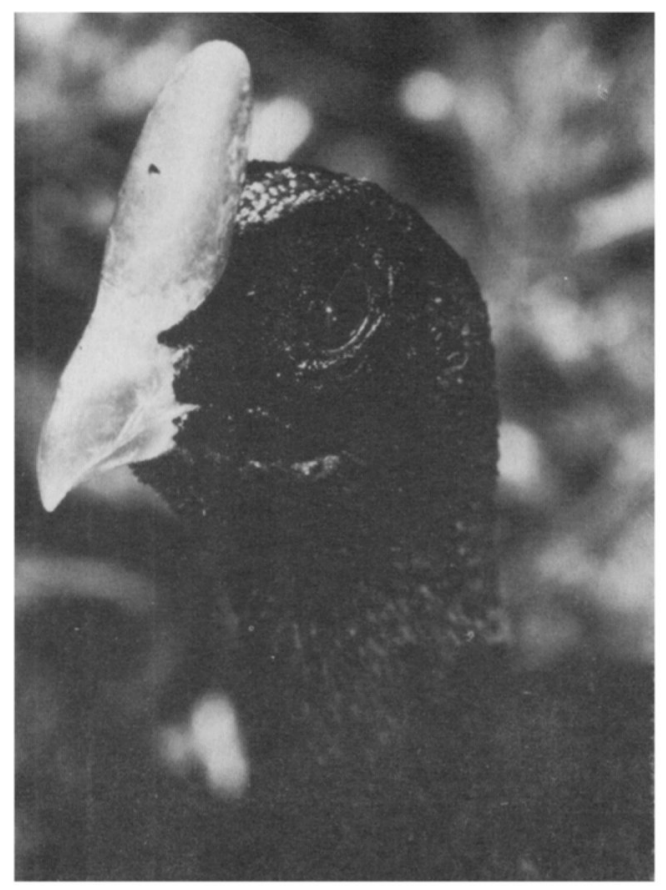

Southern helmeted (or horned) curassow Pauxi unicornis. This endangered and little-known species is rapidly disappearing from its former range in Bolivia and Peru due to widespread hunting and habitat destruction (S. D. Strahl/WCI-New York Zoological Society). 


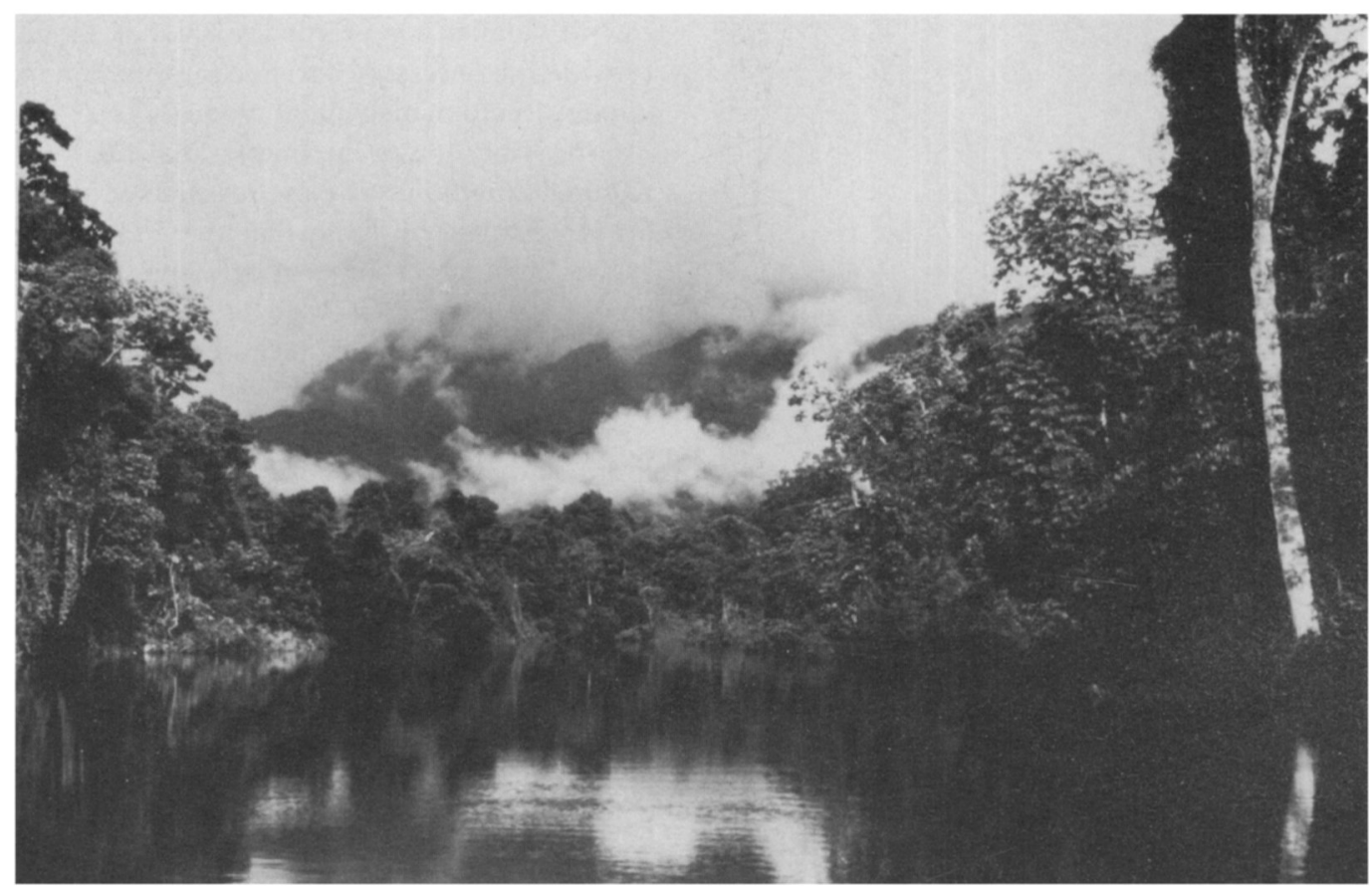

Lowland rain forest at a remote site in the Caura river basin, Venezuela. Studies and surveys of wildlife in such undisturbed locations are important to gather baseline information for application to monitoring programmes of wildlife (S. D. Strahl/WCI-New York Zoological Society).

of our strategies for conservation and management of Neotropical forests.

Because large frugivores may be critical ecological and economic components of Neotropical protected areas, both the extent of human disturbances (hunting, habitat destruction and trade) and population responses of target species must be quantified. Long-term ecological studies of wild populations should include estimates of natural densities, home ranges, recruitment rate and diet. This information, combined with information on the use of non-endangered species by hunters or trappers can be extremely valuable in the planning of long-term conservation of large tropical frugivores and of Neotropical forests as a whole.

\section{Conclusions}

Studies on large avian frugivores can be among the most crucial factors in the future management of Neotropical forests, and must not be overlooked in conservation planning.
By and large, nature reserves in the Neotropics lack active management beyond their declaration. Widespread hunting and habitat destruction are common in most of these reserves. Protected areas must be designed in part with particular high-risk species in mind, and these should be emphasized as indicators of the welfare of the ecosystem. However, few scientific investigations and practical recommendations are available for decision-making by governments throughout Latin America. Therefore, studies on species management within protected areas can have far-reaching effects. Whether it be as food, ornamentation, pet trade, sport hunting, seed dispersal or indicator species, large forest birds can have an impact on the present and future economies of Latin American countries (Delacour and Amadon, 1973; Pasquier, 1981; UNAM, 1981). These arguments must be used to attract government attention to these species as important national renewable resources. On the other hand, these studies should be designed to produce results that are 
meaningful to national interests. Aesthetic arguments, although appealing to some individuals, need to be backed by more convincing arguments of sustainable development at local and national levels.

The above recommendations obviously represent a large financial commitment. More scientists should be enlisted actively in these investigations to a far greater extent than they are currently. Most importantly, local scientists and students in Latin America should play an important role in this research. Conservation money should be largely directed toward long-term detailed research and more interdisciplinary participation of local and international conservationists.

\section{References}

Broad, S. 1986. Imports of psittacines into the UK (1981-1984). Traffic Bulletin, III, 36-44.

Collar, N.J. and Andrew, P. 1988. Birds to Watch: The ICBP Check-List of Threatened Birds. Tech. Publ. No. 8, ICBP, Cambridge.

Delacour, J. and Amadon, D. 1973. Curassows and Related Birds. American Museum of Natural History, New York.

Desenne, P. and Strahl, S.D. in press. Trade and the conservation status of the Family Psittacidae in Venezuela. Proceedings, Parrot Working Group Meeting, Curitiba, Brazil.

Diamond, A.W. and Lovejoy, T.E. 1985. Conservation of Tropical Forest Birds. Tech. Publ. No. 5, ICBP, Cambridge.

Erard, C. and Sabatier, D. 1988. Rôle des oiseaux frugivores terrestres dans la dynamique forestiére en Guyane française. In: Acta XIX Congressus Internationalis Ornithologici (ed $\mathrm{H}$. Ouillet), pp. 803-815. University of Ottawa Press, Ottawa.

Estrada, A. and Fleming, T.H. 1986. Frugivores and Seed Dispersal. Junk Publishers, Dordrecht, The Netherlands.

Janzen, D.H. (ed.) 1983. Costa Rican Natural History. University of Chicago Press, Chicago.

Lanning, D.V. and Shiflett, J.T. 1983. Nesting ecology of thick-billed parrots. Condor, 85, 66-73.

Leck, C.F. 1979. Avian extinctions in an isolated trop- ical wet forest reserve, Ecuador. $A u k, 96,343-352$.

Nilsson, G. 1985. Importation of Birds into the United States, 1980-1986. Animal Welfare Institute, Washington, DC.

Pasquier, R.F. 1981. Conservation of New World Parrots. Smithsonian Institution Press/ICBP, Washington, DC.

Ridgely, R.S. 1981. The current distribution and status of mainland Neotropical parrots. In: Conservation of New World Parrots (ed. R.F. Pasquier), pp. 233-384. Smithsonian Institution Press/ICBP, Washington, DC.

Robinson, J.G. and Redford, K. in press. Neotropical Wildlife: Use and Conservation. University of Chicago Press, Chicago.

Silva, J.L. and Strahl, S.D. in press. Human impact on populations of chachalacas, guans and curassows in Venezuela. In: Neotropical Wildlife: Use and Conservation (eds J. Robinson and K. Redford), University of Chicago Press, Chicago.

Strahl, S.D. in press. Guans, Curassows, and Chachalacas: Status Survey and Conservation Action Plan. IUCN, Gland, Switzerland.

Terborgh, J. 1986. Keystone plant resources in the tropical forest. In Conservation Biology (ed. M. E. Soule), pp. 330-344. Sinauer Associates, Sunderland, MA.

Texeira, D.M. and Snow, D.W. 1981. Notes on the nesting of the red-billed curassow, Crax blumenbachii. Bull. Brit. Orn. Club , 102, 83-84.

Thiollay, J.M. 1989. Area requirements for the conservation of rain forest raptors and game birds in French Guiana. Conservation Biology, 3, 128-137.

Thomsen, J.B. and Munn, C.A. 1988. Cyanopsitta spixii: a non-recovery report. Parrotletter, 1, 6-7.

UNAM (Univ. Nacional Autonomu de Mexico) 1981. Primer Simposio Internacional de la Familia Cracidae: Memorias. UNAM, Cocoyoc, Mexico.

Wheelwright, N.T. 1983. Fruits and the ecology of resplendent quetzals. Auk, 100, 286-301.

World Resources Institute. 1990. World Resources 1990-91. Oxford University Press, New York.

Stuart D. Strahl, Wildlife Conservation International, New York Zoological Society, 185th St \& Southern Blvd, Bronx, NY 10460, USA.

Alejandro Grajal, Department of Zoology, 223 Bartram Hall, University of Florida, Gainesville, FL 32611, USA. 